\title{
Effect of Rotational Speed on The Production Capacity of Bamboo Charcoal Particle Sieving Machine
}

\author{
Johanes Wawan Joharwan ${ }^{a}$, Martinus Heru Palmiyanto ${ }^{b}$ \\ ${ }^{a, b}$ Program Studi Teknik Mesin, Sekolah Tinggi Teknologi Warga Surakarta \\ Jalan Raya Solo-Baki KM. 2, Kwarasan, Solo Baru, Sukoharjo, Jawa Tengah, Indonesia \\ Telp. (0271) 621176, 621178 / Fax. (0271) 621178 \\ joharwan.jw@gmail.com
}

\begin{abstract}
Abstrak
Tujuan dari penelitian ini adalah untuk mempelajari pengaruh kecepatan rotasi pada mesin pengayak untuk kapasitas produksi ayakan partikel arang bambu. Mekanisme pengayakan sedang dikembangkan. Ayakan menggunakan 100 dan 200 mesh dengan kecepatan rotasi digunakan 120 rpm, 150 rpm dan $180 \mathrm{rpm}$ selama 15 menit untuk mengayak $50 \mathrm{gr}$ partikel arang bambu. Dalam penelitian ini, proses pengayakan dapat menghasilkan kapasitas produksi ayakan partikel arang bambu 18,78 gr pada 200 mesh dengan kecepatan rotasi 180 rpm.
\end{abstract}

Kata kunci: kecepatan rotasi, kapasitas produksi ayakan, mesin pengayak, partikel arang bambu

\begin{abstract}
The aim of this research is to study the effect of rotational speed on the sieving machine for the production capacity of bamboo charcoal particle sieve. A new sieving mechanism is developed. The sieves used 100 and 200 mesh with rotational speed used $120 \mathrm{rpm}, 150 \mathrm{rpm}$ and $180 \mathrm{rpm}$ for 15 minutes to sieve 50 gr of bamboo charcoal particle. In this research, the sieving process can produce production capacity sieve of bamboo charcoal particle of $18.78 \mathrm{gr}$ at 200 mesh with rotational speed of $180 \mathrm{rpm}$.
\end{abstract}

Keywords: rotational speed, production capacity sieve, sieving machine, bamboo charcoal particle

\section{INTRODUCTION}

Carbon is a unique and indispensable element in our world, the 6th element in the universe, the 4th element in the solar system and the 17th element in the Earth's crust [1]. It has been estimated that the relative abundance of carbon is between 180 and 270 parts per million [2]. Remarkably, carbon is also the second most common element in the human body after oxygen [3], thus making about 18 percent of a human's body weight. Although, elemental carbon is sparse on the earth's crust with barely $0.2 \%$ of the total mass of this planet [1] [2] [4], however, its function is incredibly essential as it can form bonds with other light elements and itself. As a result, the ability of carbon to paved the way on which chemistry and biology have been expanded, and eventually making the wonders of life to occur [3]. As such, carbon science is very trendy today and in the field of nanoscience, materials science, engineering and technology, carbon nanostructures are identified to comprise of different low-dimension allotropes of carbon including graphite, activated carbon, carbon nanotubes, and polyaromatic molecules [5] [6] [7] [8] and graphene [9] [10] [11]. This is the reason why researchers from various scientific backgrounds are very curious about this carbon material by considering the key role they have played in many new advanced technologies [12].

Bamboo has high potential as a substitute for many lignocellulosic and nonlignocellulosic materials in various application capacities because of their chemical composition and physical properties. Bamboo is also a source of quality activated carbon, which can be found in the medicine, foods, chemical and metallurgical industries [13]. Bamboo charcoals are multi-functional materials pyrolysed from bamboo under anaerobic 
conditions. During this pyrolytic process, bamboo is converted to stable charcoal. Bamboo charcoal serves as a substitute for wood charcoal or mineral coal and has been reported to possess absorption capacity which is six times that of wood charcoal of the same weight [14]. Hence, bamboo charcoal is a suitable absorbent. Studies have also revealed their uses as absorbent for dyes [15] [16], heavy metal [17] [18], organic pollutants [19] and other substances [20] [21].

Carbon-based nanomaterials, such as bamboo charcoal nanoparticles has been used in many fields, such as in microorganism [22], composites [23] [24] [25] [26], and Biomedical [27]. Bamboo charcoal nanoparticles synthesized with High Energy Milling (HEM) method on the particle size reduction using shaker mill [28] [29]. Particle size distribution is the most important parameters of characterization of nanoparticles [30]. Determination of particle size distribution using a sieving machine before the shaker mill process in order to obtain homogeneous particles.

Sieving is known as one of the most useful, simple, reproducible, and inexpensive methods of particle size analysis, and belongs to the techniques using the principle of geometry similarity. It is considered the only method for giving a particle size distribution based on the mass of particles in each size range. Particle size is defined by the sieve aperture by which a particle may, or may not, pass through [31].

Among all the elements of the sieving operation, sieve blinding is considered as the most important and direct controlling factor. Sieve blinding occurs when particles block up and lodge in the sieving mesh. It reduces the effective transfer area on the surface, resulting in reduction of sieving rates (sieving performance or capacity) and the degree of sharpness of particle separation (sieving efficiency) [31][32] [33].

With regard to the sieving process, either for industrial separation of solid particles or as a laboratory method in size analysis, a stack of sieves of decreasing mesh size, also known as a sifter cascade, is often used [34]. The sieve stack is typically mounted on a device that provides vibration or shaking to achieve the movement of particles in relation to the sieve surface. For example, in flour milling, breakage of particles is always followed by separation. A plansifter, a stack of sieves of decreasing mesh size that separate particles by size, is the main equipment used for this separation purpose. On a laboratory scale, standard ASAE procedure for particle size analysis of particulate materials also requires use of a stack of sieves [35]. For simplicity, this common sieving process is referred to as the stacked or cascaded sieve method. It features separation of particles in a coarse to fine order by a single operation.

Numerous studies reveal, the comparison of the reverse sieve method and the stacked sieve method for sieving performance and efficiency using flours made from soft white and hard white wheat, hulless barley and medium grain rice [36]. The design and manufacture of electromagnetic sieving machines that convert electromagnetic energy into mechanical energy aims to assess the powder particle size and granular particle distribution of agricultural products, Garri. The choice of Electromagnetic Sieving Machine is to increase the amplitude of the oscillation and thus reduce the sieving time [37]. The developed of an easily operated and user friendly sieving machine to sieve pound of yam flour in a process plant [38].

This research is for the development of sieving machines to get the maximum bamboo charcoal particle sieve production capacity. Sieving machine uses a new mechanism of the shaker model. One factor is to get the maximum sieve production capacity with rotational speed. The aim of this research is to study the effect of rotational speed on the sieving machine for the production capacity of bamboo charcoal particle sieve. The sieves used 100 and 200 mesh with the rotational speed used $120 \mathrm{rpm}, 150 \mathrm{rpm}$ and $180 \mathrm{rpm}$ for 15 minutes to sieving $50 \mathrm{gr}$ of bamboo charcoal particle.

\section{Methods}

Different types of sieve shaker have been created. In this research, a new sieve shaker mechanism is developed (Figure 1(a)). The sieve shaker mechanism is obtained from rotational motion changed to translational motion by connecting rod (Figure 1(b)). The speed of the motor can be controlled and the length of the stroke is determined by the length of the connecting rod. 


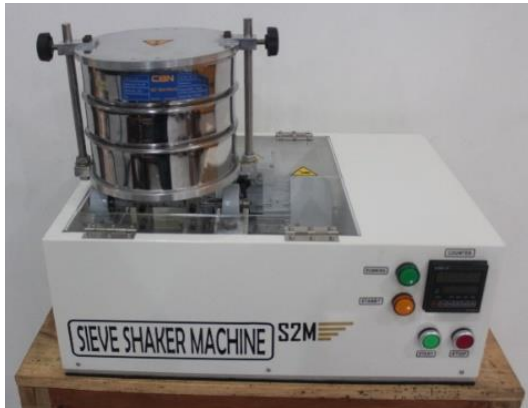

(a)

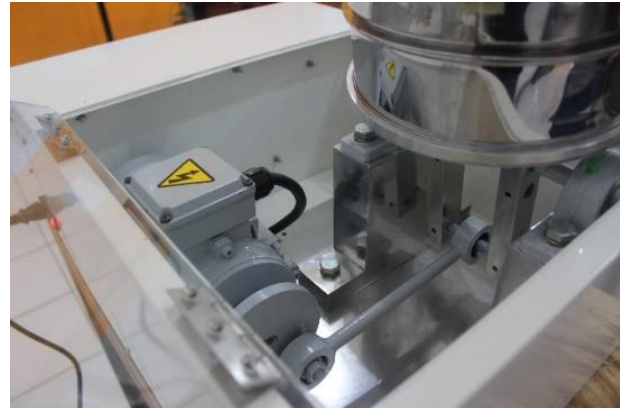

(b)

Figure 2.1. Materials used in this research (a) sieve shaker (b) connecting rod.

The sieve was made from stainless steel with 100 mesh and 200 mesh. The contents of the 100 mesh sieve are 50 gram of bamboo charcoal powder. The sieve, pan, cover and bamboo charcoal are put into the oven for 5 minutes at 200 degrees Celsius. The process of sieving bamboo charcoal with rotational speed uses $120 \mathrm{rpm}, 150 \mathrm{rpm}$ and $180 \mathrm{rpm}$ for 15 minutes. In this study, the number of repetitions was done ten times. The best data that meets the standard deviation is displayed as the sieve production capacity.

\section{Result AND Discussion}

The sieve production capacity at 100 mesh are shown in Figure 2. The largest weight of 26.27 grams is produced by the rotational speed of $180 \mathrm{rpm}$ at 100 mesh. Weighing 25.85 grams and 24.09 grams is produced by $150 \mathrm{rpm}$ and $120 \mathrm{rpm}$ at 100 mesh. It can be seen that an increase in rotational speed of 120,150 and $180 \mathrm{rpm}$ causes the weight of bamboo charcoal powder to be sieved to become more.

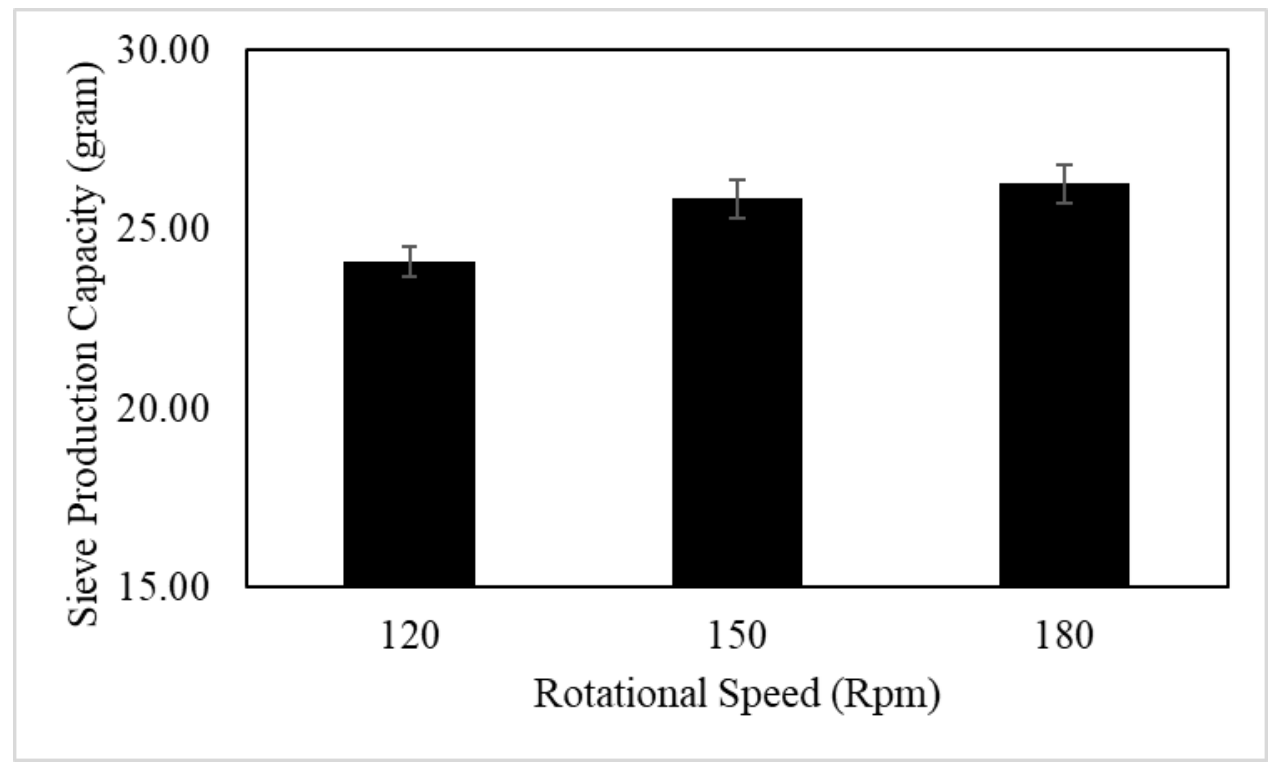

Figure 3.1. Sieve production capacity at 100 mesh

The sieve production capacity at 200 mesh are shown in Figure 3 . The largest weight of 18.78 grams is produced by the rotational speed of $180 \mathrm{rpm}$ at 200 mesh. Weighing 18.05 grams and 17.71 grams is produced by $150 \mathrm{rpm}$ and $120 \mathrm{rpm}$ at 200 mesh. It can be seen that an increase in rotational speed of 120,150 and $180 \mathrm{rpm}$ causes the weight of bamboo charcoal powder to be sieved to become more. 


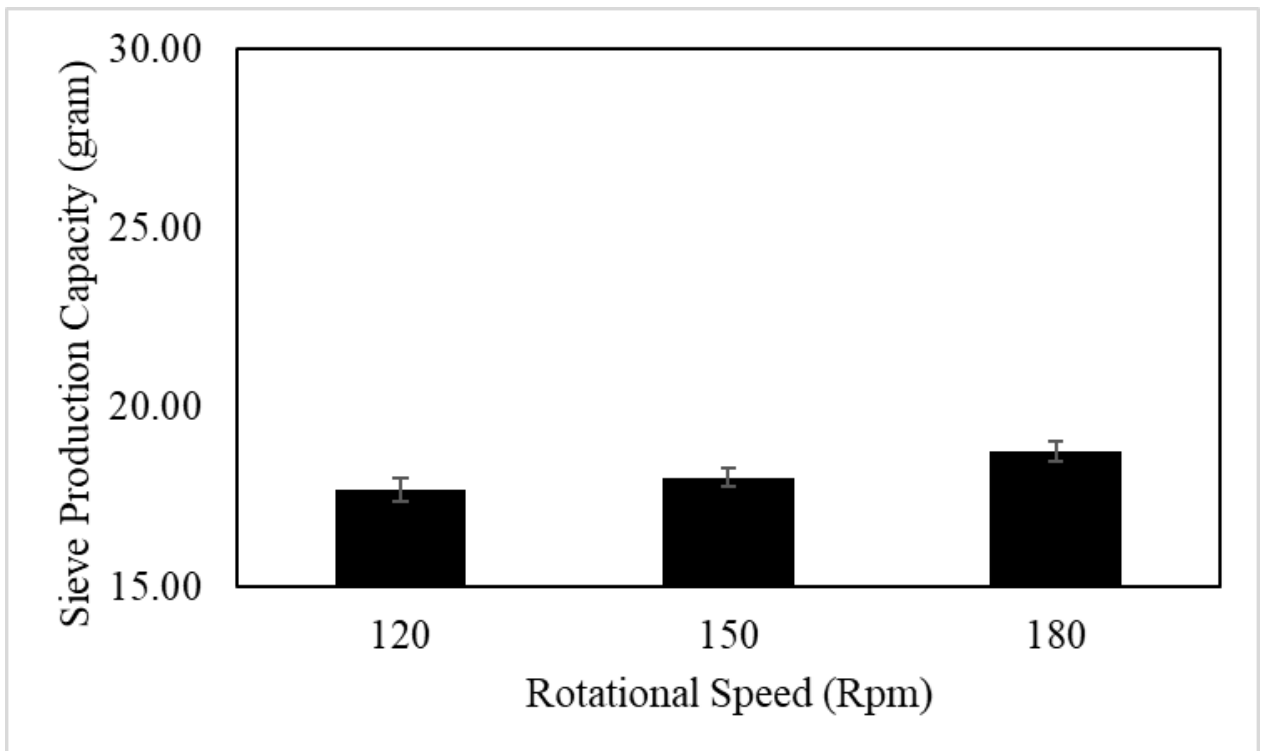

Figure 3.2 Sieve production capacity at 200 mesh

The moisture level of a particulate material affects such physical properties as adhesion and stickiness, which in turn influence freedom of particle movement during the sieving process [34]. For a given sieving condition and given particulate material, there will be a moisture level that allows maximum freedom of particle movement.

\section{Conclusion}

The sieving machine can be used to sieving a bamboo charcoal powder with a production capacity of 26.27 grams at 100 mesh and 18.78 grams at 200 mesh with a rotational speed of $180 \mathrm{rpm}$. It seems that bamboo charcoal is a potential source to produce nano particle of pure carbon.

\section{ACKNOWLEDGMENTS}

This work is supported by Research Institute of Sekolah Tinggi Teknologi Warga Surakarta.

\section{REFERENCES}

[1] Y. Zhang and Q.-Z. Yin, "Carbon and other light element contents in the Earth's core based on first-principles molecular dynamics," Proc Natl Acad Sci U S A (PNAS), vol. 109, no. 48, pp. 19579-19583, 2012.

[2] C. J. Allegre, J.-P. Poirier, E. Humler and A. W. Hofmann, "The chemical composition of the Earth," Earth and Planetary Science Letters, no. 134, pp. 515-526, 1995.

[3] N. R. Pace, "The universal nature of biochemistry," Proc Natl Acad Sci U S A (PNAS), vol. 98, no. 3, pp. 805-808, 2001.

[4] B. Marty, C. M. O. Alexander and S. N. Raymond, "Primordial Origins of Earth's Carbon," Mineralogy \& Geochemistry, vol. 75, pp. 149-181, 2013.

[5] M.-M. Titirici, R. J. White, N. Brun, V. L. Budarin, D. S. Su, F. d. Monte, J. H. Clark and M. J. MacLachlan, "Sustainable carbon materials," Chemical Society Reviews, vol. 44, no. 1, pp. 250-290, 2015.

[6] M. Loos, "Allotropes of Carbon and Carbon Nanotubes," in Carbon Nanotube Reinforced Composites, Elsevier, 2015, pp. 73-101.

[7] J. Deng, Y. You, V. Sahajwalla and R. K. Joshi, "Transforming waste into Carbon-based Nanomaterials".

[8] F. Rodríguez-reinoso, "The role of carbon materials in heterogeneous catalysis," Carbon, vol. 36, no. 3, pp. 159-175, 1998. 
[9] M. J. Allen, V. C. Tung and R. B. Kaner, "Honeycomb Carbon : A Review of Graphene," Chemical Reviews, vol. 110, no. 1, pp. 132-145, 2010.

[10] A. K. Geim and K. S. Novoselov, "The rise of graphene," Nature Materials, vol. 6, pp. 183-191, 2007.

[11] K. S. Novoselov, V. I. Fal'ko, L. Colombo, P. R. Gellert, M. G. Schwab and K. Kim, "A roadmap for graphene," Nature, vol. 490, pp. 192-200, 2012.

[12] S. Nasir, M. Z. Hussein, Z. Zainal and N. A. Yusof, "Carbon-Based Nanomaterials / Allotropes : A Glimpse of Their Synthesis, Properties and Some Applications," Materials, vol. 11, no. 295, pp. 1-24, 2018.

[13] M. A. Azeez and J. I. Orege, "Bamboo, Its Chemical Modification and Products," in Current and Future Prospects, IntechOpen, 2018, pp. 25-48.

[14] M. Lobovikov, S. Paudel, M. Piazza, H. Ren and J. Wu, Worl bamboo resources : A themathic study prepared in the framework of the Global Forest Resources Assessment 2005, Rome: Food and Agriculture Organization of the United Nations (FAO), 2007.

[15] Y. Liu, X. Zhao, J. Li, D. Ma and R. Han, "Characterization of bio-char from pyrolysis of wheat straw and its evaluation on methylene blue adsorption," Desalination and Water Treatment, vol. 46, pp. 115-123, 2012.

[16] Y.-Y. Yang, Z.-L. Li, G. Wang, X.-P. Zhao, D. E. Crowley and Y.-H. Zhao, "Computational Identification and Analysis of the Key Biosorbent Characteristics for the Biosorption Process of Reactive Black 5 onto Fungal Biomass," PLOS ONE, vol. 7, no. 3, pp. 1-8, 2012.

[17] K. Lu, X. Yang, G. Gielen, N. Bolan, Y. S. Ok, N. K. Niazi, S. Xu, G. Yuan, X. Chen, X. Zhang, D. Liu, Z. Song, X. Liu and H. Wang, "Effect of bamboo and rice straw biochars on the mobility and redistribution of heavy metals $(\mathrm{Cd}, \mathrm{Cu}, \mathrm{Pb}$ and $\mathrm{Zn})$ in contaminated soil," Journal of Environmental Management, vol. 186, pp. 285-292, 2017.

[18] F. Y. Wang, H. Wang and J. W. Ma, "Adsorption of cadmium (II) ions from aqueous solution by a new low-cost adsorbent--bamboo charcoal," Journal of Hazardous Materials, vol. 177, pp. 300-306, 2010.

[19] J. W. Ma, F. Y. Wang, Z. H. Huang and H. Wang, "Simultaneous removal of 2,4dichlorophenol and $\mathrm{Cd}$ from soils by electrokinetic remediation combined with activated bamboo charcoal," Journal of Hazardous Materials, vol. 176, pp. 715-720, 2010.

[20] T. Asada, T. Ohkubo, K. Kawata and K. Oikawa, "Ammonia adsorption on bamboo charcoal with acid treatment," Journal of Health Science, vol. 52, no. 5, pp. 585-589, 2006.

[21] Z. Zhou, J. Yuan and M. Hu, "Adsorption of ammonium from aqueous solutions on environmentally friendly barbecue bamboo charcoal: Characteristics and kinetic and thermodynamic studies," Environmental Progress \& Sustainable Energy, pp. 1-8, 2014.

[22] B. She, X. Tao, T. Huang, G. Lu, Z. Zhao, C. Guo and Z. Dang, "Effects of nano bamboo charcoal on PAHs-degrading strain Sphingomonas sp. GY2B," Ecotoxicology and Environmental Safety 125, pp. 35-42, 2015.

[23] C.-S. Chou, C.-Y. Chen, S.-H. Lin, W.-H. Lu and P. Wu, "Preparation of TiO2 / bamboocharcoal-powder composite particles and their applications in dye-sensitized solar cells," Advanced Powder Technology, pp. 1-7, 2015.

[24] C.-M. Tang, Y.-H. Tian and S.-H. Hsu, "Poly(vinyl alcohol) Nanocomposites Reinforced with Bamboo Charcoal Nanoparticles : Mineralization Behavior and Characterization," Materials, pp. 4895-4911, 2015.

[25] S. Zhu, Y. Guo, Y. Chen, N. Su, K. Zhang and S. Liu, "Effects of the Incorporation of Nano-Bamboo Charcoal on the Mechanical Properties and Thermal Behavior of Bamboo-Plastic Composites," BioResources, vol. 11, no. 1, pp. 2684-2697, 2016.

[26] M. Mousa and D. Yu, "The Role of Nanoparticles Shape and Structures in Material Characterisation of Polyvinyl Alcohol (PVA) Bionanocomposite Films," Polymers, pp. 124, 2020.

[27] X. Dong, W. Yin, J. Yu, R. Dou, T. Bao, X. Zhang, L. Yan, Y. Yong, C. Su, Q. Wang, Z. 
Gu and Y. Zhao, "Mesoporous Bamboo Charcoal Nanoparticles as New Near-Infrared Responsive Drug Carrier for Imaging-Guided Chemotherapy / Photothermal Synergistic Therapy of Tumor," Advanced Healthcare Materials, pp. 1-11, 2016.

[28] H. Lyu, B. Gao, F. He, C. Ding, J. Tang and J. C. Crittenden, "Ball-Milled Carbon Nanomaterials for Energy and Environmental Applications," ACS Sustainable Chemistry \& Engineering, vol. 5, pp. 9568-9585, 2017.

[29] Supriyono, Ngafwan and J. W. Joharwan, "The effect of the ball size on the product characteristics of shaker HEM to produce nano particle from bamboo charcoal," International Conference on Engineering and Applied Technology (ICEAT), pp. 1-6, 2017.

[30] S. L. Pal, U. Jana, P. K. Manna, G. P. Mohanta and R. Manavalan, "Nanoparticle : An overview of preparation and characterization," Journal of Applied Pharmaceutical Science, pp. 228-234, 2011.

[31] G. V. Barbosa-Canovas, E. O. Rivas, P. Juliano and H. Yan, "Food Powders : Physical Properties, Processing, and Functionality," in Separation and Classification, New York, Kluwer Academic/Plenum Publishers, 2005, pp. 247-270.

[32] K. Leschonski, "Powder Technology 24," in Sieve Analysis, the Cinderella of Particle Size Analysis Methods, Elsevier, 1979, pp. 115-124.

[33] T. A. Roberts and J. K. Beddow, "Powder Technoloy 2," in Some Effects of Particle Shape and Size upon Blinding During Sieving, Elsevier, 1968, pp. 121-124.

[34] T. Allen, "Powder Sampling and Particle Size Determination," in 4 - Particle size analysis by sieving, Elsevier Science, 2003, pp. 208-250.

[35] ASABE (American Society of Agricultural and Biological Engineers) Standars, "Method of Determining and Expressing Fineness of Feed Materials by Sieving," 2006.

[36] K. Liu, "Powder Technology 193," in Some Factors Affecting Sieving Performance and Efficiency, vol. Powder Technology 193, Elsevier, 2009, pp. 208-213.

[37] U. A.J. and E. K.O., "Experimental Analysis of Particle Size Distribution using Elektromagnetic Sieve," American Journal of Engineering Research (AJER), vol. 02, no. 10, pp. 77-85, 2013.

[38] A. S.P., O. O.M. and A. B.O., "Development and Performance Evaluation of a Sieving Machine for Poundo Yam Process Plant," Journal of Emerging Trends in Engineering and Applied Sciences (Jeteas), vol. 5, no. 4, pp. 229-236, 2014. 